\section{Pretreatment Effects on Seed Germination of Two Nyssa Species}

\author{
Frank Balestri and William R. Graves ${ }^{1}$ \\ Department of Horticulture, Iowa State University, Ames, IA 50011-1100
}

Additional index words. dormancy, propagation, stratification, tetrazolium

\begin{abstract}
The genus Nyssa L. includes several woody species with traits valued by horticulturists, but only black gum (Nyssa sylvatica Marsh.) is prevalent in the nursery trade. A congener, swamp tupelo ( $N y s s a$ biflora Walt.), might be a marketable shade tree, but little is known about propagating it from seeds. Because cold, moist stratification overcomes embryo dormancies of black gum, we compared germination of cleaned seeds (surrounding pulp of fruits removed) of swamp tupelo and black gum that were stratified at $5{ }^{\circ} \mathrm{C}$ for $0,14,28,42,56,70,84$, and 112 days. Seeds of swamp tupelo within intact drupes were also stratified. Across all durations of stratification, $79 \%$ of cleaned seeds of swamp tupelo germinated, whereas $11 \%$ of seeds within drupes germinated. Germination value of cleaned seeds of swamp tupelo increased from 1.26 to 3.23 as duration of stratification increased. Although cleaned seeds of black gum responded similarly, the benefit of stratification was more pronounced, and the mean germination percentage was lower than for swamp tupelo (66\% vs. $79 \%)$. In a second experiment, irrigation with low and high concentrations of an extract of fruit pulp of swamp tupelo reduced germination of seeds of basil (Ocimum basilicum L. 'Superbo'), spinach (Spinacea oleracea L. 'Bloomsdale'), zinnia (Zinnia $\times$ marylandica Spooner, Stimart, and Boyle 'Double Zahara Cherry'), and swamp tupelo by $25 \%$ to $63 \%$ (low concentration) and $40 \%$ to $\mathbf{7 0} \%$ (high concentration). Propagators should remove the surrounding pulp from seeds of swamp tupelo and cold stratify them at least for 4 weeks.
\end{abstract}

Nyssa biflora Walt. (swamp tupelo) is indigenous to swamps and bottomlands of the southeastern United States. The species distribution comprises the coastal plain from Delaware to south Florida and east Texas, and extends north to southern Illinois. In contrast, $N$. sylvatica Marsh. (black gum) is indigenous to much of the eastern United States and occurs from Maine to southern Ontario, to central Missouri, and to eastern Texas and southern Florida. Although swamp tupelo is not marketed for horticultural use, black gum is promoted in the industry as a specimen tree with a strong central leader that supports distinctively stratified scaffold limbs and glossy, colorful foliage. Considered among the most beautiful trees native to North America, cultivars of black gum provide outstanding autumnal foliar color and desirable canopy architecture (Dirr, 2009). Taxonomic confusion may help to explain why swamp tupelo is not a nursery crop. Black gum and swamp tupelo can be challenging to differentiate (Outcalt, 1990), and swamp tupelo has been regarded as a variant of black gum [N. sylvatica var. biflora (Walt.) Sarg.]. Embryological studies suggest that swamp tupelo is more closely related to Nyssa aquatica L. (water tupelo) than to

Received for publication 2 Mar. 2016. Accepted for publication 26 Mar. 2016.

We thank Steve McNamara and Byron Carmean for assistance with collection of seeds, and the J. Frank Schmidt Family Charitable Foundation for financial assistance.

${ }^{1}$ Corresponding author. E-mail: graves@iastate. edu. black gum (Tandon and Herr, 1971), and Burckhalter (1992) distinguished swamp tupelo from black gum as one of five North American species of Nyssa.

Naturally occurring in soils usually, but not necessarily constantly, waterlogged (Applequist, 1956; Penfound, 1952), swamp tupelo may thrive where fluctuations in soil moisture and aeration are common. Unlike swamp tupelo, wild plants of black gum are not restricted to wetlands, but instead occur on a soil moisture gradient of dry uplands to alluvial stream bottoms and occasionally on edges of swamps (McGee, 1990). Plants that occupy sites in nature that are flooded seasonally or continuously not only resist stresses that afflict other species in inundated soils, but may also tolerate or resist stress from water deficit (Li and Zhong, 2006). The popular tree bald cypress (Taxodium distichum L.) is one of the numerous species important for horticulture that illustrate the tendency for flood-resistant trees to resist drought also. Within the genus Nyssa, differences in their occurrence in nature underscore the possibility that the highly flood-tolerant swamp tupelo may respond more favorably than black gum to a wide range of soil water contents. Aesthetic features of swamp tupelo include glossy green summer foliage and scarlet-red autumnal color.

Its beauty and potential resistance to extremes in soil moisture justify exploring the potential for using swamp tupelo in horticulture. Propagation protocols are needed by horticultural scientists to generate plants for evaluation and by commercial growers. We focused on propagation of swamp tupelo from seed because of success with other members of the genus. All species of Nyssa form seeds within fleshy drupes. Dirr and Heuser (2006) noted that seeds of black gum can germinate with pulp of drupes intact, although it is unknown whether pulp enhances or impedes seed germination of $\mathrm{Nyssa}$ spp. Fagan et al. (1981) demonstrated that seeds of lily turf [Liriope muscari (Decne.) L.H. Bailey] with their mealy covering intact had a lower germination rate than seeds with coverings removed. Norton (1980) found similar effects of removing the aril from seeds of southern magnolia (Magnolia grandiflora L.). Kobayashi et al. (2010) suggested that accumulation of abscisic acid (ABA) in the flesh of fruit of watermelon [Citrullus lanatus (Thunb.) Mansf.] may prevent viviparous germination. Seed germination of spicebush (Lindera benzoin L.) was nearly 100\% when fruits were manually cleaned or regurgitated by American robins (Turdus migratorious L.), but was $<1 \%$ when pulp remained intact (Cipollini and Levey, 1997). We therefore quantified the seed germination of Nyssa spp. by using both intact drupes and seeds cleaned of pulp. Cold stratification is required to overcome dormancy of seeds of many species from temperate climates. Although stratification effects may vary with seed provenance, seeds of black gum stratified at $4{ }^{\circ} \mathrm{C}$ for 3 months germinated well (Dirr and Heuser, 2006). On the basis of its distribution in regions with relatively mild winters, we hypothesized that seeds of swamp tupelo are less resistant to germination than seeds of black gum, thus requiring shorter durations of stratification to release embryo dormancy.

Our first objective was to determine effects of pulp removal and duration of cold stratification on the speed, synchrony, and total germination of seeds of swamp tupelo. Because treatments were based on those reported to promote seed germination of black gum, seeds of both species were studied. After results suggested that the pulp of drupes of swamp tupelo contains inhibitors that impede seed germination, our second objective became to test that possibility with seeds of swamp tupelo and three other species.

\section{Materials and Methods}

Experiment 1. Drupes of swamp tupelo were collected in late 2013 from trees indigenous to two sites in Virginia, Seacock Chapel Swamp in Zuni, and adjacent to Lake Prince in Suffolk, and from trees indigenous to Hoke County, NC. Drupes of black gum were collected from a cultivated tree at the Minnesota Landscape Arboretum, Chanhassen, MN.

Cold, moist stratification of seeds that were cleaned (pulp surrounding endocarps removed by maceration in tap water) or of seeds within intact drupes was initiated on 22 Nov. 2013. An experimental unit comprised 20 seeds of either swamp tupelo or black gum in a polyethylene bag $(11 \times 15 \mathrm{~cm})$ that contained $100 \mathrm{~cm}^{3}$ of coarse sand moistened with $400 \mathrm{~mL}$ of tap water. Units were held in 
a dark cooler at $5{ }^{\circ} \mathrm{C}$ except for those randomly assigned to receive no stratification. Five units were assigned randomly to each species-stratification combination. Of the five units per treatment with seeds of swamp tupelo, three contained seeds from Lake Prince, one contained seeds from Seacock Chapel Swamp, and one contained seeds from Hoke County.

After stratification treatments of $0,14,28$, $42,56,70,84$, and $112 \mathrm{~d}$, seeds or intact drupes were removed from the bags and rinsed with tap water to remove residual sand. The 20 seeds or drupes from each unit were placed on two sheets of 12-ply VersaPak $^{\mathrm{TM}}$ Cellulose Wadding (K-24; Blue Ridge Tissue Corp., Lenoir, NC) wetted with $200 \mathrm{~g}$ of tap water in a transparent, plastic germination box that was $16 \mathrm{~cm} \times 27 \mathrm{~cm} \times 4 \mathrm{~cm}$. Boxes were randomly assigned a position on 12 shelves in a germination chamber with five boxes per shelf. The chamber was equipped with six cool-white fluorescent lamps and programmed at alternating day/ night temperatures of $30 / 20{ }^{\circ} \mathrm{C}$ for $8 / 16 \mathrm{~h}$, respectively.

Germination, defined as the initial emergence of the radicle during $56 \mathrm{~d}$ in the germination chamber, was monitored daily. Mean daily germination was determined as the germination percentage per experimental unit divided by 56 , the number of days of the germination period. Peak value was the cumulative germination percentage for each experimental unit on the single day when the most seeds germinated (peak day), divided by the number of days required to reach that germination percentage. The product of peak value and mean daily germination, germination value, was determined as a composite expression of the rate and completeness of germination (Czabator, 1962). Germination percentage was determined on day 56. Experimental units in which no seeds germinated were ascribed a 56 for germination distribution and peak day, the poorest score possible. Germination distribution was the number of days between the first and last days that germination occurred in an experimental unit. Seedlings were removed from boxes as germination progressed. Viability of seeds that did not germinate was tested with tetrazolium (2,3,5-triphenyltetrazolium chloride; Peters, 2000). Distal ends of the cotyledons of seeds were removed, and seeds were soaked in a $1 \%$ solution of tetrazolium for $12 \mathrm{~h}$ at $35{ }^{\circ} \mathrm{C}$, before embryos and endosperms were removed from seeds and visually deemed viable, not viable, or absent.

Analyses of variance (ANOVA) were performed $\left(\mathrm{JMP}^{\circledR} 11\right.$ software; JMP ${ }^{\circledR}$, Version 11, SAS Institute Inc., Cary, NC, 19892007) on germination value, percentage, and distribution; peak day and value; and mean daily germination. The Tukey's honestly significant difference option of the software was used to separate means. Data representing cleaned seeds of swamp tupelo and black gum were analyzed together to assess the effects of species, stratification, and their interaction. A separate analysis was done of data that represented cleaned seeds and intact drupes of swamp tupelo to assess the effects of stratification, pulp, and their interaction.

Experiment 2. An extract of fruit pulp of swamp tupelo was generated by macerating the fleshy exterior of drupes in deionized water $(20 \mathrm{~mL}$ of water per 50 fruits). The slurry was strained to remove solids $>1 \mathrm{~mm}$. This initial extract was diluted with either two (high concentration) or four (low concentration) parts by volume of deionized water. These extract solutions were used as irrigation treatments along with a deionizedwater control. The pour-through method was used to collect leachate from containers in which seeds were evaluated for germination (Torres et al., 2010). Across all treatments, $\mathrm{pH}$ of the leachate ranged from 6.1 to 6.4 , and electrical conductivity ranged from 0.36 to $0.55 \mathrm{dS} \cdot \mathrm{m}^{-1}$

Ten seeds of $O$. basilicum L. 'Superbo' (basil), S. oleracea L. 'Bloomsdale' (spinach), Z. ×marylandica Spooner, Stimart, and Boyle 'Double Zahara Cherry' (zinnia), or swamp tupelo (cleaned of pulp) were sown in each of 12 replicate containers $(7.5 \mathrm{~cm}$ tall, $8.5 \mathrm{~cm}$ across tops, and $6.5 \mathrm{~cm}$ across bottoms) filled with $\mathrm{LC} 1$ growing medium (Sunshine ${ }^{\circledR}$ Mix No. 1; Sun Gro Horticulture, Agawan, MA). The containers were randomly arranged on one shelf of a growth chamber in which the environment was similar to that used for Experiment 1. To initiate the three treatments, four containers with seeds from each species were irrigated with $80 \mathrm{~mL}$ of one of the extracts or with the control. An additional $15 \mathrm{~mL}$ was applied to each container 5 and $6 \mathrm{~d}$ later. Because of a limited supply of extract solutions, each container was placed in an individual sealed plastic bag after the irrigation on day 6 to reduce desiccation of the medium. Germination, defined as the visual emergence of a hypocotyl above the container medium, was recorded after $14 \mathrm{~d}$. Effect of irrigation treatment was assessed with ANOVA and Tukey's honestly significant difference test with the software used for Experiment 1.

\section{Results}

Experiment 1: Main effects for cleaned seeds of swamp tupelo and black gum. Species differed for germination value $(P \leq$ $0.0031)$, germination percentage $(P \leq$ $0.0001)$, peak day $(P \leq 0.0001)$, peak value $(P \leq 0.0001)$, and mean daily germination $(P \leq 0.0001)$, but not germination distribution. Stratification affected germination value $(P \leq 0.0001)$, germination percentage $(P \leq$ $0.0001)$, germination distribution $(P \leq$ $0.031)$, peak day $(P \leq 0.0001)$, peak value $(P \leq 0.0001)$, and mean daily germination $(P \leq 0.0001)$. An interaction of species and stratification existed for germination value $(P \leq 0.0198)$, germination percentage $(P \leq$ $0.0001)$, peak day $(P \leq 0.0001)$, peak value $(P \leq 0.0103)$, and mean daily germination $(P \leq 0.0001)$, but not for germination distribution.
Experiment 1: Main effects for swamp tupelo. Cleaning seeds of pulp influenced germination value $(P \leq 0.0001)$, germination percentage $(P \leq 0.0001)$, germination distribution $(P \leq 0.0258)$, peak day $(P \leq 0.0001)$, peak value $(P \leq 0.0001)$, and mean daily germination $(P \leq 0.0001)$. Stratification influenced germination value $(P \leq 0.0005)$ and peak value $(P \leq 0.0003)$. Effects of pulp and stratification interacted only for germination value $(P \leq 0.0053)$ and peak value $(P \leq 0.0004)$

Experiment 1: Means by species for cleaned seeds. Averaged over durations of stratification, germination percentage for swamp tupelo was 1.2 times than that of black gum (Table 1). Peak day of germination of swamp tupelo was nearly a week earlier than that of black gum (Table 1). Peak value and mean daily germination for swamp tupelo were 1.4 and 1.2 times than those of black gum (Table 1). The species had similar mean germination values and distributions (Table 1).

Experiment 1: Pulp effects on swamp tupelo. Averaged over durations of stratification, germination value of cleaned seeds was 217 times greater than that of seeds within intact fruits (Table 1), and cleaning seeds increased germination by $65.7 \%$ (Table 1 ). Germination distribution and the peak day of germination were $8.4 \mathrm{~d}$ shorter and $32.3 \mathrm{~d}$ earlier, respectively, for cleaned seeds than for seeds within fruits (Table 1). Peak value and mean daily germination of cleaned seeds were 37 and seven times than those, respectively, of seeds within fruits (Table 1).

Experiment 1: Duration of stratification. Germination value, germination percentage, germination distribution, peak day, peak value, and mean daily germination of seeds of swamp tupelo within intact fruits were unaffected by duration of stratification (Table 2). For cleaned seeds of swamp tupelo, only germination value and peak value were affected by treatment and increased with increasing duration of stratification (Table 2).

Germination of cleaned seeds of black gum was influenced strongly by duration of stratification. Germination value increased linearly with stratification time (Fig. 1) from $<0.01$ at $0 \mathrm{~d}$ of stratification to 3.49 after $112 \mathrm{~d}$ of stratification (Table 2), and the slope of the increase was greater than that for swamp tupelo (Fig. 1). Only 1\% of seeds of black gum germinated without stratification, whereas $96 \%$ germinated after stratification for $112 \mathrm{~d}$ (Table 2). Germination distribution was maximal with $0 \mathrm{~d}$ of stratification and decreased to 17.4 with $112 \mathrm{~d}$ of stratification (Table 2). Peak day was as late as 50.6 without stratification and decreased to 7.2 with $112 \mathrm{~d}$ of stratification (Table 2). Mean daily germination was 0.01 with no stratification and increased to 1.71 with $112 \mathrm{~d}$ of stratification (Table 2).

Experiment 1: Tetrazolium tests. Overall durations of stratification, $81.4 \%$ of seeds of swamp tupelo that did not germinate within intact fruits were viable and $5.9 \%$ were not 
Table 1. Comparison of germination responses of cleaned seeds of swamp tupelo (Nyssa biflora) and black gum (Nyssa sylvatica) and cleaned seeds and seeds within intact fruits of swamp tupelo across all times of stratification. Cleaned seeds and seeds within intact fruits were stratified for $0,14,28,42,56,70,84$, and $112 \mathrm{~d}$ in the dark at $5^{\circ} \mathrm{C}$. Values for species/pulp combinations are means of 40 multiseed replications.

\begin{tabular}{|c|c|c|c|c|c|c|c|}
\hline \multirow[b]{2}{*}{ Main effects } & \multirow[b]{2}{*}{ Cleaned } & \multicolumn{3}{|c|}{ Germination } & \multicolumn{2}{|c|}{ Peak } & \multirow{2}{*}{$\frac{\text { Mean daily germination }}{(\% / \mathrm{d})}$} \\
\hline & & Value & $\%$ & $\overline{\text { Distribution (d) }}$ & Day & $\overline{\text { Value }}$ & \\
\hline \multicolumn{8}{|l|}{ Species } \\
\hline Swamp tupelo & Yes & $2.17 \mathrm{~A}^{\mathrm{z}}$ & $78.6 \mathrm{~A}$ & $16.9 \mathrm{~A}$ & $6.9 \mathrm{~B}$ & $7.4 \mathrm{~A}$ & $1.4 \mathrm{~A}$ \\
\hline Black gum & Yes & $1.68 \mathrm{~A}$ & $65.8 \mathrm{~B}$ & $20.9 \mathrm{~A}$ & $13.5 \mathrm{~A}$ & $5.4 \mathrm{~B}$ & $1.2 \mathrm{~B}$ \\
\hline \multicolumn{8}{|l|}{ Pulp } \\
\hline Swamp tupelo & No & $0.01 \mathrm{~b}^{\mathrm{y}}$ & $11.1 \mathrm{~b}$ & $25.3 \mathrm{a}$ & $39.2 \mathrm{a}$ & $0.2 \mathrm{~b}$ & $0.2 \mathrm{~b}$ \\
\hline Swamp tupelo & Yes & $2.17 \mathrm{a}$ & $78.6 \mathrm{a}$ & $16.9 \mathrm{~b}$ & $6.9 \mathrm{~b}$ & $7.4 \mathrm{a}$ & $1.4 \mathrm{a}$ \\
\hline
\end{tabular}

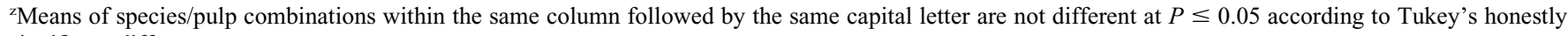
significant difference test.

y Means of species/pulp combinations within the same column followed by the same lowercase letter are not different at $P \leq 0.05$ according to Tukey's honestly significant difference test.

Table 2. Comparison of germination responses of seeds of swamp tupelo (Nyssa biflora) and black gum (Nyssa sylvatica) stratified for 0 to $112 \mathrm{~d}$. Values are means of five replications.

\begin{tabular}{|c|c|c|c|c|c|c|}
\hline \multirow[b]{2}{*}{ Time of stratification of species/treatment combinations } & \multicolumn{3}{|c|}{ Germination } & \multicolumn{2}{|c|}{ Peak } & \multirow{2}{*}{$\frac{\text { Mean daily germination }}{(\% / \mathrm{d})}$} \\
\hline & Value & $\%$ & Distribution (d) & Day & Value & \\
\hline \multicolumn{7}{|l|}{ Swamp tupelo (not cleaned) } \\
\hline 0 & $0.01 \mathrm{a}^{\mathrm{z}}$ & $11 \mathrm{a}$ & $31.6 \mathrm{a}$ & $48.4 \mathrm{a}$ & $0.15 \mathrm{a}$ & $0.20 \mathrm{a}$ \\
\hline 14 & $0.01 \mathrm{a}$ & $8 \mathrm{a}$ & $6.2 \mathrm{a}$ & $31.6 \mathrm{a}$ & $0.18 \mathrm{a}$ & $0.14 \mathrm{a}$ \\
\hline 28 & $<0.01 \mathrm{a}$ & $5 \mathrm{a}$ & $24.4 \mathrm{a}$ & $42.0 \mathrm{a}$ & $0.12 \mathrm{a}$ & $0.10 \mathrm{a}$ \\
\hline 42 & $<0.01 \mathrm{a}$ & $6 \mathrm{a}$ & $12.4 \mathrm{a}$ & $53.0 \mathrm{a}$ & $0.10 \mathrm{a}$ & $0.11 \mathrm{a}$ \\
\hline 56 & $0.02 \mathrm{a}$ & $18 \mathrm{a}$ & $31.2 \mathrm{a}$ & $34.2 \mathrm{a}$ & $0.21 \mathrm{a}$ & $0.32 \mathrm{a}$ \\
\hline 70 & $0.02 \mathrm{a}$ & $14 \mathrm{a}$ & $23.4 \mathrm{a}$ & $35.8 \mathrm{a}$ & $0.30 \mathrm{a}$ & $0.25 \mathrm{a}$ \\
\hline 84 & $0.01 \mathrm{a}$ & $11 \mathrm{a}$ & $40.6 \mathrm{a}$ & $37.6 \mathrm{a}$ & $0.14 \mathrm{a}$ & $0.20 \mathrm{a}$ \\
\hline 112 & $0.02 \mathrm{a}$ & $16 \mathrm{a}$ & $32.8 \mathrm{a}$ & $31.0 \mathrm{a}$ & $0.21 \mathrm{a}$ & $0.29 \mathrm{a}$ \\
\hline \multicolumn{7}{|l|}{ Swamp tupelo (cleaned) } \\
\hline 0 & $1.26 \mathrm{~b}$ & $71 \mathrm{a}$ & $18.8 \mathrm{a}$ & $8.4 \mathrm{a}$ & $4.89 \mathrm{c}$ & $1.27 \mathrm{a}$ \\
\hline 14 & $1.41 \mathrm{~b}$ & $79 \mathrm{a}$ & $23.8 \mathrm{a}$ & $5.0 \mathrm{a}$ & $5.00 \mathrm{bc}$ & $1.41 \mathrm{a}$ \\
\hline 28 & $1.73 \mathrm{ab}$ & $69 \mathrm{a}$ & $12.6 \mathrm{a}$ & $10.2 \mathrm{a}$ & $6.00 \mathrm{~b}$ & $1.23 \mathrm{a}$ \\
\hline 42 & $3.02 \mathrm{ab}$ & $90 \mathrm{a}$ & $16.2 \mathrm{a}$ & $5.8 \mathrm{a}$ & $9.39 \mathrm{ab}$ & $1.61 \mathrm{a}$ \\
\hline 56 & $2.07 \mathrm{ab}$ & $79 \mathrm{a}$ & $19.8 \mathrm{a}$ & $6.2 \mathrm{a}$ & $7.33 \mathrm{abc}$ & $1.41 \mathrm{a}$ \\
\hline 70 & $2.41 \mathrm{ab}$ & $78 \mathrm{a}$ & $18.4 \mathrm{a}$ & $5.8 \mathrm{a}$ & $8.33 \mathrm{abc}$ & $1.39 \mathrm{a}$ \\
\hline 84 & $2.26 \mathrm{ab}$ & $80 \mathrm{a}$ & $19.6 \mathrm{a}$ & $6.6 \mathrm{a}$ & $7.81 \mathrm{abc}$ & $1.42 \mathrm{a}$ \\
\hline 112 & $3.23 \mathrm{a}$ & $83 \mathrm{a}$ & $5.6 \mathrm{a}$ & $7.0 \mathrm{a}$ & $10.71 \mathrm{a}$ & $1.48 \mathrm{a}$ \\
\hline \multicolumn{7}{|l|}{ Black gum (cleaned) } \\
\hline 0 & $<0.01 \mathrm{~d}$ & $1 \mathrm{c}$ & $45.0 \mathrm{a}$ & $50.6 \mathrm{a}$ & $0.03 \mathrm{~d}$ & $0.01 \mathrm{c}$ \\
\hline 14 & $0.04 \mathrm{~d}$ & $16 \mathrm{c}$ & $14.2 \mathrm{~b}$ & $12.2 \mathrm{~b}$ & $0.76 \mathrm{~d}$ & $0.29 \mathrm{c}$ \\
\hline 28 & $1.01 \mathrm{~cd}$ & $67 \mathrm{~b}$ & $11.8 \mathrm{~b}$ & $9.8 \mathrm{~b}$ & $4.15 \mathrm{c}$ & $1.20 \mathrm{~b}$ \\
\hline 42 & $1.81 \mathrm{bc}$ & $85 \mathrm{a}$ & $28.2 \mathrm{ab}$ & $7.0 \mathrm{~b}$ & $5.94 \mathrm{bc}$ & $1.52 \mathrm{a}$ \\
\hline 56 & $2.20 \mathrm{~b}$ & $86 a$ & $20.2 \mathrm{ab}$ & $7.4 \mathrm{~b}$ & $7.15 \mathrm{~b}$ & $1.54 \mathrm{a}$ \\
\hline 70 & $2.81 \mathrm{ab}$ & $94 \mathrm{a}$ & $15.8 \mathrm{~b}$ & $6.0 \mathrm{~b}$ & $8.33 \mathrm{ab}$ & $1.68 \mathrm{a}$ \\
\hline 84 & $2.10 \mathrm{~b}$ & $81 \mathrm{ab}$ & $14.6 \mathrm{~b}$ & $7.4 \mathrm{~b}$ & $7.03 \mathrm{~b}$ & $1.45 \mathrm{ab}$ \\
\hline 112 & $3.49 \mathrm{a}$ & $96 \mathrm{a}$ & $17.4 \mathrm{ab}$ & $7.2 \mathrm{~b}$ & $10.13 \mathrm{a}$ & $1.71 \mathrm{a}$ \\
\hline
\end{tabular}

${ }^{\mathrm{z}}$ Means of species-treatment combinations within a column followed by the same letter are not different at $P \leq 0.05$ according to Tukey's honestly significant difference test.

viable; embryos were absent in $12.7 \%$ of seeds. For cleaned seeds of swamp tupelo that did not germinate, $41.5 \%$ were viable, $25.2 \%$ not viable, and $33.3 \%$ lacked an embryo. Among cleaned seeds of black gum that did not germinate, $90.5 \%$ were viable, $2.6 \%$ not viable, and $6.9 \%$ lacked an embryo.

Experiment 2. Irrigation with aqueous extracts of the pulp of drupes of swamp tupelo decreased germination of all taxa. For basil, irrigation with water and the lower and higher concentrations of extract resulted in mean germination of $65 \%, 40 \%$, and $3 \%$, respectively, and the means for seeds treated with water and the higher concentration of extract were different at $P \leq 0.05$. The corresponding results for spinach were $45 \%, 3 \%$, and $3 \%$; for zinnia were $73 \%$, $10 \%$, and $3 \%$; and for swamp tupelo were $45 \%, 18 \%$, and $5 \%$, respectively. For those three species, means for seeds treated with water and either concentration of extract were different at $P \leq 0.05$, and means for seeds treated with the two extract concentrations were not different.

\section{Discussion}

Our results are significant to horticulture in three ways. First, we have shown that cold stratification enhances speed and uniformity of germination of cleaned seeds of swamp tupelo, a species that may have untapped potential for the nursery industry. Second, our hypothesis that seeds of swamp tupelo are less resistant to germination than seeds of black gum was supported. Lastly, we have shown that extracts of the fruit pulp of swamp tupelo inhibit germination of seeds of swamp tupelo and other species. We conclude that swamp tupelo can be propagated reliably from seeds removed from fruits, which would allow for selection from a wide array of genotypes for desired ornamental or physiological traits. Selections should focus on staminate trees of this polygamodioecious species to avoid its drupes, which, although typically $<2 \mathrm{~cm}$ long and $<1 \mathrm{~cm}$ wide, may raise maintenance concerns.

Germination value, an especially meaningful measure of germination (Czabator, 1962), and peak value, which represents the vigorousness of germination on the peak day, were highest for cleaned seeds of swamp tupelo stratified for $112 \mathrm{~d}$ (Table 2). Therefore, although a germination percentage of $\approx 70$ can be achieved without stratifying cleaned seeds (Table 2), we recommend that propagators stratify for up to $112 \mathrm{~d}$ to improve the rate of germination. Slopes of the linear regression functions that best represented the relationship between time of stratification and germination value (Fig. 1) show that seeds of black gum are more responsive to stratification than seeds of swamp tupelo. Using germination value as 


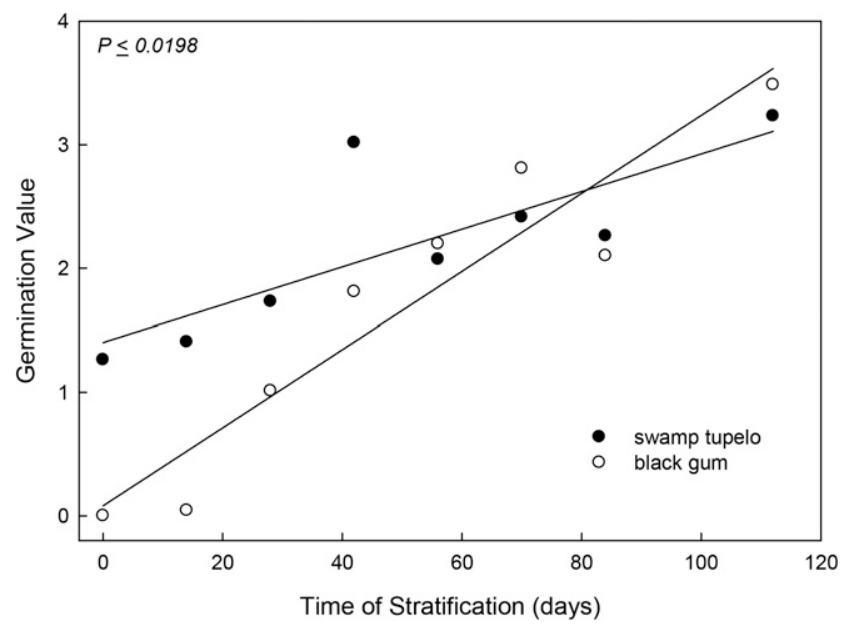

Fig. 1. Interaction of species and stratification for germination value of cleaned seeds of swamp tupelo (Nyssa biflora) and black gum (Nyssa sylvatica) represented by linear regression. For swamp tupelo, germination value $=0.0152 \mathrm{x}+1.4019, r^{2}=0.65$, and $P \leq 0.0164$. For black gum, germination value $=$ $0.0316 \mathrm{x}+0.0809, r^{2}=0.89$, and $P \leq 0.0004$. Each filled or open symbol represents the mean of five replications. The value for $P$ in the upper left hand corner indicates that two lines better represent germination value than one line, thereby confirming the interaction.

a composite expression of germination, we concluded that germination of seeds of black gum was optimized when stratified for $112 \mathrm{~d}$ (Table 2). Although this treatment evoked a germination percentage that would satisfy most propagators (96\%; Table 2), longer stratification might have led to additional germination because tetrazolium tests confirmed the viability of nearly all seeds of black gum that did not germinate. Peak value of cleaned seeds of black gum was affected by time of stratification, whereas the effect on peak day was less pronounced (Table 2). This was due to an increase in germination percentage on the peak day with increasing time of stratification. The range of the swamp tupelo is restricted to the southeastern United States where winters are relatively short and mild, which is consistent with seeds of swamp tupelo requiring a shorter period of chilling than seeds of black gum.

Germination of seeds of swamp tupelo within drupes was poor (Table 1) and unaffected by stratification (Table 2). Our finding that $81.4 \%$ of seeds that did not germinate were viable, along with the roughly seventimes higher germination percentage of seeds of swamp tupelo removed from drupes (Table 1), strongly supports our conclusion that fruit pulp inhibits germination of swamp tupelo. Evenari (1949) and Mayer and PoljakoffMayber (1989) noted that fruits sometimes contain germination inhibitors. Kobayashi et al. (2010) concluded that the presence of ABA in fruit pulp of watermelon may restrict germination. ABA plays a dynamic role in events during seed development such as prevention of precocious germination and induction of primary dormancy; thus, future research might include tests for the presence of ABA in the fruit pulp of swamp tupelo.
Seeds in intact fruits of a woody species may differ in germination responses based on the maternal source (Meyer and Witmer, 1998), and differences in nutrient composition of fruits (Cipollini and Stiles, 1992) and in the amount of fruit pulp covering the seed may explain variation in germination due to presence of pulp (Barnea et al., 1991; Howe, 1980; Howe and Vande Kerckhove, 1981; Izhaki and Safriel, 1990). Fruit pulp and exocarps with relatively thick cuticular layers can inhibit germination via osmotic pressure from dissolved sugars and reduced permeability of water (Mayer and PoljakoffMayber, 1989). Our research was neither designed to quantify differences among maternal seed sources nor to characterize whether germination responses vary based on wild provenance (Bischoff et al., 2006). Future researchers could address these questions, and explore effects of fruit pulp on seed water relations.

\section{Literature Cited}

Applequist, M.B. 1956. A study of soil and site factors affecting the growth and development of swamp black gum and tupelogum stands in southeast Georgia. Duke Univ., Durham, NC, $\mathrm{PhD}$ Diss.

Barnea, A., Y. Yom-tov, and J. Friedman. 1991. Does ingestion by birds affect seed germination? Funct. Ecol. 5:394-402.

Bischoff, A., B. Vonlanthen, T. Steinger, and H. Müller-Schärer. 2006. Seed provenance matters: Effects on germination of four plant species used for ecological restoration. Basic Appl. Ecol. 7:347-359.

Burckhalter, R.E. 1992. The genus Nyssa (Cornaceae) in North America: A revision. SIDA Contrib. Bot. 15:323-342.

Cipollini, M.L. and E.W. Stiles. 1992. Relative risks of microbial rot for fleshy fruits:
Significance with respect to dispersal and selection for secondary defense. Adv. Ecol. Res. 23:35-91.

Cipollini, M.L. and D.J. Levey. 1997. Secondary metabolites of fleshy vertebrate-dispersed fruits: Adaptive hypotheses and implications for seed dispersal. Amer. Nat. 150:346-372.

Czabator, F.J. 1962. Germination value: An index combining speed and completeness of pine seed germination. For. Sci. 8:386-396.

Dirr, M.A. 2009. Manual of woody landscape plants: Their identification, ornamental characteristics, culture, propagation and uses. 6th ed. Stipes Pub., Champaign, IL.

Dirr, M.A. and C.W. Heuser. 2006. The reference manual of woody plant propagation: From seed to tissue culture: A practical working guide to the propagation of over 1100 species, varieties, and cultivars. Varsity Press, Cary, NC.

Evenari, M. 1949. Germination inhibitors. Bot. Rev. 15:153-194.

Fagan, A.E., M.A. Dirr, and F.A. Pokorny. 1981. Effects of depulping, stratification, and growth regulators on seed germination of Liriope muscari. HortScience 16:208-209.

Howe, H.F. 1980. Monkey dispersal and waste of a neotropical fruit. Ecology 61:944-959.

Howe, H.F. and G.A. Vande Kerckhove. 1981. Removal of wild nutmeg Virola surinamensis crops by birds. Ecology 62:1093-1106.

Izhaki, I. and U.N. Safriel. 1990. The effect of some Mediterranean scrubland frugivores upon germination patterns. Ecology 78: $56-65$.

Kobayashi, Y., K. Nabeta, and H. Matsuura. 2010. Chemical inhibitors of viviparous germination in the fruit of watermelon. Plant Cell Physiol. 51:1594-1598.

Li, C.X. and Z.C. Zhong. 2006. Photosynthetic physio-response of Taxodium ascendens seedlings to different soil water gradients. For. Res. 19:54-60.

Mayer, A.M. and A. Poljakoff-Mayber. 1989. The germination of seeds, p. 270. 3rd ed. Pergamon Press, New York.

McGee, C.E. 1990. Black tupelo. In: R.M. Burns and B.H. Honkala (eds.). Silvics of North America. USDA Forest Service Agriculture Handbook 654, Washington, D.C.

Meyer, G.A. and M.C. Witmer. 1998. Influence of seed processing by frugivorous birds on germination success of three North American shrubs. Amer. Midl. Nat. 140:129-139.

Norton, C.R. 1980. Deleterious metabolic and morphological changes resulting from seed soaking prior to sowing. Proc. Intl. Plant Prop. Soc. 30:132-134.

Outcalt, K.W. 1990. Swamp tupelo. In: R.M. Burns and B.H. Honkala (eds.). Silvics of North America. USDA Forest Service Agriculture Handbook 654, Washington, D.C.

Penfound, W.T. 1952. Southern swamps and marshes. Bot. Rev. 8:413-446.

Peters, J. 2000. Tetrazolium testing handbook. Assoc. Official Seed Analysts, Contrib. 29.

Tandon, S.R. and J.M. Herr, Jr. 1971. Embryological features of taxonomic significance in the genus Nyssa. Can. J. Bot. 49:505-514.

Torres, A.P., M.V. Mickelbart, and R.G. Lopez. 2010. Leachate volume effects on $\mathrm{pH}$ and electrical conductivity measurements in containers obtained using the pour-through method. HortTechnology 20:608-611. 